\title{
Familial Malignant Melanoma - Overview
}

\author{
Tadeusz Dębniak \\ International Hereditary Cancer Center, Department of Genetics and Pathology, Pomeranian Medical University, Szczecin, Poland
}

Key words: familial melanoma, genetic factors

Corresponding author: Tadeusz Dębniak, International Hereditary Cancer Center, Department of Genetics and Pathology, Pomeranian Medical University, Połabska 4, 70-115 Szczecin, Poland, e-mail: debniak@wp.pl

Submitted: 20 May 2004

Accepted: 19 July 2004

\begin{abstract}
Approximately 3-15\% of all malignant melanomas (MM) are familial cases. MM is a highly heterogeneous tumour type from a genetic perspective. Pedigrees with disease confined to a single generation of siblings or MM occurring among second- or third-degree relatives suggest multifactorial polygenic inheritance. However, not infrequently, within large families aggregations of $M M$ are consistent with autosomal dominant inheritance, suggesting a hereditary syndrome caused by germline alterations of a single gene. Several different genes are involved in the development of MM. However, even when taken together they are responsible for less than $20 \%$ of all MM cases. It is thus necessary to perform association studies focused on genetic markers that could be used in identifying patients with a high risk of $\mathrm{MM}$. Evaluation of aggregations of $\mathrm{MM}$ and other malignancies, like breast cancer, could be essential in identifying relatives of $M M$ probands being at high risk of developing malignancies other than $M M$. The ultimate goal is to apply in these cases prevention recommendations and surveillance protocols to reduce the disease risk.
\end{abstract}

\section{Epidemiology}

Malignant melanoma (MM) is one of the most aggressive human malignancies. The incidence rates differ among Caucasian populations: $\sim 35$ per 100000 in Australia [1], 10 per 100000 in the United States [2], 7-10 per 100000 in Western Europe [3, 4]. Its incidence has increased dramatically over the past years in Caucasian population worldwide up to a 10 -fold increase since 1950s [5].

\section{Risk factors}

\section{Sun exposure}

Well-established environmental risk factor of $M M$ is ultraviolet radiation (UV), sunburn and overexposure to the sun [6]. Armstrong and Kricker estimated that up to
$65 \%$ of MM could be related to sunburn [7]. Exposure in childhood seems to be an especially important risk factor [8]. In countries with a growing awareness of MM and public health campaigns to avoid UV a downturn in MM incidence has been observed [9].

\section{Genetic factors}

It has been long stated in many different reviews that genetic susceptibility is another major MM risk factor. Recent epidemiological studies confirm these suggestions. Evaluation of over eight thousand Swedish probands with primary MM revealed that the familial risk for offspring of affected parents is about 2.57, and even higher (4.22) when a parent has been diagnosed at an age $<50$ years [10]. Similar results were obtained during the evaluation of $1505 \mathrm{MM}$ probands recorded in Utah (USA) when the familial risk for first-degree 
relatives (both offspring and siblings) was 2.1 , and as high as 6.52 when MM cases were diagnosed under 50 years [1 1]. Hemminki et al reported that the familial MM risk showed a clear age dependence and higher risk in in situ melanoma than in its invasive counterpart [12].

Familial clustering of MM has also been studied in twins. A population-based study of cancer risk in twins performed by Swerdlow et al indicated an increased risk of the occurrence of MM in opposite-sex co-twins, however studies performed by Hemminki and Milan did not confirm these results [13, 14, 15].

Familial aggregations of malignancy may be due to either genetic factors, environmental factors shared by family members, or both. In a recent study Czene et al assessed the genetic and environmental components in the main types of cancer by statistical analyses of family pairs. The importance of genetic effects was indicated by a higher correlation among relatives that were more closely related to each other genetically. Structural equation modelling was used to derive estimates of the importance of environmental and genetic effects. A statistically significant proportion of susceptibility to cancer accounted for by genetic effects was obtained for almost all malignancies, including MM. It was estimated that in the case of MM genetic factors constitute $21 \%$ of susceptibility, similarly to other neoplasms, such as cancers of breast, colon or stomach [16].

\section{Familial aggregations of MM}

There are two distinct ways of defining familial melanoma: 1) occurrence of melanoma in at least two first-degree relatives; or 2) families with at least two melanomas irrespective of the degree of relationship.

Approximately $3-15 \%$ of all MM are familial cases

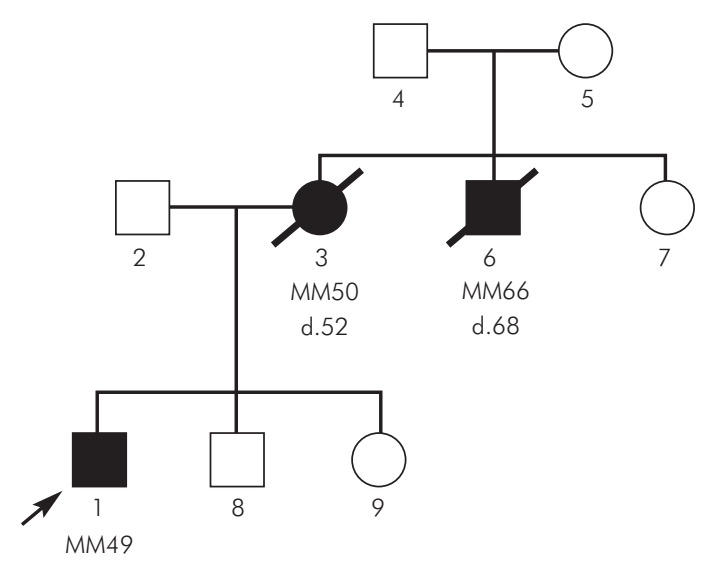

Fig. 1. Pedigree of a family with melanoma diagnosed among first-degree relatives registered in our center of any type [17]. In Australia, Holman and Armstrong found a positive family history in 15\% of 507 cases (9.9\% in first-degree relatives) [18]. In the USA MM was present in first-degree relatives in $4.1 \%$ of 116 cases [19], in Denmark among 474 patients $4.7 \%$ had a relative with $M M$ (3\% in first-degree relatives) [20]. In our center among 405 unselected MM patients 12 cases (3\%) had at least one first-degree relative affected.

In several families the co-occurrence of melanoma of the skin and the eye is reported [21]. The question whether ocular melanoma is also part of the familial melanoma syndrome remains unanswered.

Familial MM constitutes most probably a heterogeneous group of disorders characterized by occurrence of MM among relatives. The mode of inheritance is controversial and according to Mao is most likely polygenic [22]. Pedigrees with disease confined to a single generation of siblings or $\mathrm{MM}$ occurring among second-or third-degree relatives suggest multifactorial polygenic inheritance. However, not infrequently, within large families aggregations of MM are consistent with autosomal dominant inheritance. Anderson et al described MM in at least 15 members of a three-generation kindred. Early age of onset and a tendency for multiple primary lesions were characteristic features [23]. Lynch and Krush (1968) described two families with malignant melanoma in two generations in one family and three generations in the other [24]. Such pedigrees strongly suggest that part of familial MM constitutes hereditary syndrome caused by single-gene germline alterations. In order to identify such families the first definition of familial melanoma described above should be used.

\section{Familial aggregations of $M M$ and malignancies at different sites of origin}

Aggregations of MM and other malignancies have been reported by many authors.

Most significantly a high incidence of pancreatic cancer has been reported in melanoma families, either by itself or in association with breast cancer [25-27].

Weston et al described a case with familial aggregation of melanoma, basal cell carcinoma and gastric cancer [28]. Aggregations of MM and cerebral astrocytoma [29], squamous cell carcinoma (SCC) [30] and kidney [31] were described. Recently, an increased risk of breast cancer among first-degree relatives of MM probands from families with strong cancer familial aggregation (showing features of autosomal dominant pattern of inheritance) has been suggested [32]. 


\section{Molecular background of familial melanoma}

\section{Genes conferring high risk of developing MM}

\section{CDKN2A}

In 1994 the first and so far the most significant high-risk MM susceptibility gene, CDKN2A (9p21, OMIM 600160) was identified [33, 34]. One of the four transcripts coded by this gene is the p 16 protein. It inhibits the activity of the complex of cyclin D1 with cyclin-dependent kinase 4 (CDK4) or 6 (CDK6), the function of which is to promote cellular proliferation [35]. Thus CDKN2A acts as a tumour suppressor gene by inhibiting cellular proliferation.

Germline mutation frequencies in CDKN2A among members of melanoma families show considerable variation. Soufir et al showed frequent involvement of CDKN2A in French familial melanoma families (46\%) whereas Fitzgerald et al identified $18 \%$ of US familial melanoma harboured CDKN2A constitutional mutations $[36,37]$. Among Swedish families only $8 \%$ of cases were found to harbour alterations in the CDKN2A gene $[38,39]$. Germline mutation and large deletion analysis of the CDKN2A/ARF genes in Polish families with multiple melanomas and in families with an aggregation of $M M$ and breast cancer revealed that less than $6 \%$ of familial MM can be associated with the CDKN2A/ARF constitutional mutations [40]. In a separate study done by Lamperska et al no CDKN2A mutations have been detected in Polish melanoma-prone families [41].

According to Bressac-de-Paillerets et al the number of CDKN2A alterations correlates with the number of $M M$ cases in the family and a young age at diagnosis $(<50)$ [42]. However, no germline mutations have been reported in childhood melanoma so far [43].

In Dutch melanoma-prone families with a specific recurrent 19bp deletion of exon 2 of the CDKN2A gene, a high frequency of pancreatic cancer was observed [44]. CDKN2A was the first of the melanoma genes and is associated with an increase in the risk of pancreatic cancer as well [45]. Occurrence of multiple $M M$, pancreatic cancer and also breast cancer has been reported in families with different recurrent CDKN2A constitutional alterations [46].

In a recent study Bishop et al examined 80 families with documented CDKN2A mutations and multiple cases of cutaneous melanoma to establish the penetrance of the CDKN2A germline mutations. The penetrance was $30 \%$ by the age of 50 and $67 \%$ by the age of 80 . It depended on the geographic origin: at 80 years of age, it was $58 \%$ in Europe, $76 \%$ in North America and $91 \%$

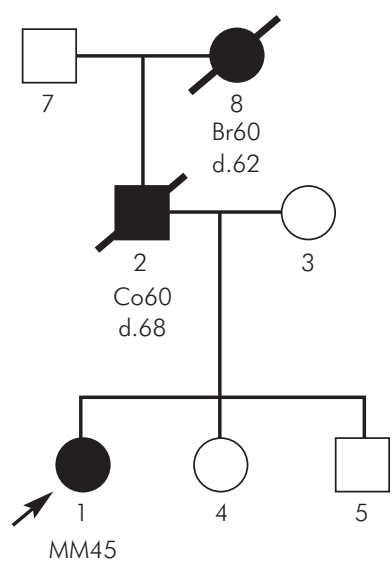

Fig. 2. Pedigree of a family with familial aggregations with $M M$ and malignancies of different site of origin

in Australia [47]. These data suggest that UV increases the penetrance of the CDKN2A mutations.

There is no doubt that regardless of the geographical origin, inclusion criteria or study methods, CDKN2A constitutional alterations have been found only in the minority of melanoma-prone families. In families with multigenerational inheritance of $\mathrm{MM}$ there remains a possibility that non-coding mutations of CDKN2A or alterations in another tumour suppressor gene predispose to familial melanoma.

\section{ARF}

In 1995 two independent groups discovered that CDKN2A shares exons 2 with another gene, ARF [48, 49]. The transcript, $\mathrm{p} 14^{\mathrm{ARF}}$ is involved in the regulation of the cell cycle and apoptosis [50]. It has also been implicated in the pathogenesis of MM. The first exon of $A R F$ is unique, whereas its second exon is derived from exon 2 of CDKN2A using a different reading frame of the sequence. Up to now mutations in ARF are reported to be present only in a few families worldwide and are characterized by an aggregation of MM and brain tumours [51]. Hewitt et al described a germline mutation of ARF in patients affected with melanoma or breast cancer from a family with multiple melanomas and breast cancers [52], in an independent study performed in our center no constitutional ARF alterations in cases with familial aggregation of MM and breast cancer were detected [40].

\section{CDK4}

In 1996 Zuo et al identified the CDK4 gene (12q13, OMIM 123829) as a third MM susceptibility gene [48]. CDK4 is an oncogene that codes the cyclin-dependent kinase 4 protein. Alterations in this gene are responsible 
for the occurrence of very small proportions of familial MM. Up to now germline CDK4 mutations have been found in 3 families world-wide [36, 53, 54].

\section{BRCA2}

Mutations in BRCA2 (13q12, OMIM 600185), acting in DNA repair, predispose to a range of cancer types. The Breast Cancer Linkage Consortium estimates the relative risk of melanoma to be 2.58 in BRCA2 carriers [55]. In 2002 Scott et al examined 71 patients with ocular MM and pedigree and clinical data suggestive of genetic background (bilateral cases, positive family history for occurrence of $M M$, age at diagnosis <50). He estimated the prevalence of possible loss of function changes in BRCA2 in 3\% of patients with familial ocular melanoma [56]. No germline BRCA2 mutations have been found in familial skin $M M$ to date. The penetrance of this gene is unknown. Johannsson et al suggested that apart from breast and ovarian cancer, the incidence of other cancer types did not appear to be greatly increased in BRCA2-associated families and did not warrant specific clinical follow-up in mutation carriers [57].

\section{NBS1}

In 1998 Varon et al mapped and cloned the gene responsible for Nijmegen breakage syndrome characterized by spontaneous chromosomal instability, immunodeficiency and predisposition to cancer. The NBS1 gene is located on 8q21 (OMIM 602667) [58]. The NBS 1 protein product, called nibrin (also referred to as p95), is an integral component of hMRE 1 1/hRAD50/NBS1 nuclease complex, acting in a double-strand break repair of human DNA [59].

Mutations in the NBS1 gene predispose to a range of cancer types. We recently reported a greater than expected prevalence of a founder 657 del 5 mutation in the NBS 1 gene in consecutive MM patients with aggregations of breast cancer but this preliminary finding needs to be confirmed [60]. No germline NBS1 mutations have been found in familial skin MM to date.

\section{CHK2}

Malignant melanoma has been suggested to belong to the clinical spectrum of Li-Fraumeni syndrome (LFS, OMIM151623). In 1999 Blasina et al and Chaturvedi et al independently identified cell-cycle-checkpoint kinase 2 (CHK2, MIM 604373), one of the key mediators of cellular responses to DNA damage $[61,62]$. The germline recurrent mutation in the CHK2 gene (1100delC in exon 10) has been found among two families with a phenotype suggestive of Li-Fraumeni syndrome [63]. The tumour spectrum of one of these families included MM. In a recent study germline 1100 delC mutation in the CHK2 gene was reported in a patient with $M M$ of the skin and three metachronous malignancies belonging to LFS tumour spectrum [64]. Thus, it seems that 1100 delC of the CHK2 gene may be responsible for occurrence of very small proportions of $M M$ cases, especially in families with Li-Fraumeni syndrome or Li-Fraumeni-like syndrome. No germline CHK2 mutations have been found in familial skin $M M$ to date.

\section{MLH1, MSH2}

Germline mutations in the MLH1 (3p21, OMIM $120436)$ and MSH2 (2p22, OMIM 120435) genes can lead to Muire-Torre syndrome, a variant of hereditary non-polyposis colorectal cancer syndrome with an increased frequency of occurrence of skin malignancies, including MM. Both genes participate in mismatch repair system of DNA. There is a report of biallelic somatic inactivation of the MLH1 gene in a primary skin melanoma [65]. It seems that a small proportion of $\mathrm{MLH1} / \mathrm{MSH} 2$ carriers could be at risk of developing MM. No germline MLH1/MSH2 mutations have been found in familial skin $M M$ to date.

\section{$X P$-genes}

$M M$, as well as a large number of basal cell carcinoma and squamous cell cancer of the skin, is a characteristic feature of xeroderma pigmentosum syndrome (XP). XP is a group of disorders characterized by high sensitivity to sunlight with the development of skin malignancies at an early age. There are several variants of XP caused by different XP susceptibility genes, all of these genes are involved in UV-damaged DNA repair. Three most common forms of XP variants are: XPA (OMIM 278700), XPC (OMIM 278720) and XPD (OMIM 278730). Recently an increased risk of cutaneous melanoma in carriers of XPD polymorphisms has been reported $[66,67]$.

In the literature we found no data about germline mutations of XPA, XPC and XPD genes in familial melanoma to date.

\section{Genes conferring a low risk of developing MM}

\section{MCIR}

The MC1R gene (16q24, OMIM 155555) codes a protein that acts as the receptor for melanocyte-stimulating hormone (MSH). It has been reported that some germline allelic variants of the MCIR gene (Arg 151 Cys, Arg 160Trp, Asp294His) conferred to fair skin/red hair phenotype associated with an increased risk of MM [68-70]. The same allelic variants independently of skin type are associated with an increased MM risk [69]. They also act as modifiers of the 
melanoma risk in carriers of the CDKN2A mutations by increasing the penetrance from 50\% to $84 \%$ in Australia and from $18 \%$ to $55 \%$ in the Netherlands $[71,72]$.

\section{Other factors}

Inherited traits explaining part of the familial risk of MM by modulating the response to UV radiation also include:

1) nevi, the risk of developing a melanoma increases with the number of nevi and their clinically atypical aspects (increase in size, red hue and/or ABCDE criteria: (A) asymmetry, (B) vague border, (C) variegated pigmentation, (D) diameter exceeding $5 \mathrm{~mm},($ E) elevation) [73, 74]. This risk is especially high in dysplastic nevus syndrome [75]. Recent twin studies indicate the contribution of both genetic factors and sun exposure to the number of nevi [76]. Analysis of familial transmission of nevi suggests a more complex mechanism than a single-gene effect [77]. Atypical nevi, present either in the familial or sporadic setting are regarded by dermatologists as strong indicators of an increased melanoma risk and should be either monitored or excised.

It should be mentioned that MM, especially a nodular type, can arise in apparently healthy skin;

2) skin type (liability to tan), the risk of $M M$ is increased in persons with fair skin (limited capabilities of tanning) and red hair [78].

\section{Conclusions}

MM is a highly heterogeneous tumour type from a genetic perspective. Pedigree and clinical data of a proportion of familial MM suggest a hereditary syndrome caused by germline alterations of a single gene. Several different genes are involved in the development of MM. However, even when taken together they are responsible for less than $20 \%$ of all MM cases. It is thus necessary to perform association studies focused on identifying genetic markers that could be used in identifying patients with a high risk of MM. Evaluation of aggregations of MM and other malignancies, like breast cancer, could be essential in identifying relatives of $M M$ probands being at high risk of developing malignancies other than MM. The ultimate goal is to apply in these cases prevention recommendations and surveillance protocols to reduce the disease risk.

\section{Prevention recommendations}

The use of higher sun protection factor sunscreens, avoidance of physical trauma of nevi.

\section{Surveillance protocols}

In the case of familial MM: melanoma patient, his first- and second degree relatives: half-yearly careful skin examination by the dermatologist. In cases with atypical nevi: skin examination should be performed every three months. Random removal of a large number of atypical nevi is not recommended. The removal of lesions in susceptible individuals should be indicated by clinical signs of malignant transformation (increase of size, red hue, bleeding, pruritus, etc.).

Additionally the melanoma patient and his relatives should be screened for pancreatic cancer with an annual ultrasonography and computer tomography every three years.

In cases with familial aggregations with MM and malignancies (at least two cases) at different sites of origin, especially with MM diagnosed under the age of 55: breast cancer surveillance is suggested (yearly physical examination, ultrasonography and finally mammography starting from the age of 25).

\section{References}

1. Marret LD, Nguyen $\mathrm{HL}$ and Armstrong BK. Trends in the incidence of cutaneous malignant melanoma in New South Wales, 1983-1996. Int J Cancer 2001; 92 (3): 457-462.

2. Jemal A, Devesa SS, Hartge P and Tucker MA. Recent trends in cutaneous melanoma incidence among whites in the United States. J Natl Cancer Inst 2001; 93 (9): 678-683.

3. Micheli A, Mugno E, Krogh V, Quinn MJ, Coleman M, Hakulinen T, Gatta G, Berrino F, Capocaccia R; EUROPREVAL Working Group. Cancer prevalence in European registry areas. Ann Oncol 2002; 13 (6): 840-845.

4. Armstrong BK and Kricker A. Cutaneous melanoma. Cancer Survey 1994; 19: 219-240.

5. Weinstock MA. Issues in the epidemiology of melanoma. Hematol Oncol Clin North Am 1998; 12: 681-698.

6. English DR, Armstrong BK, Kricker A and Fleming C. Sunlight and cancer. Review. Cancer Causes Control 1997; 8 (3): 271-283.

7. Armstrong BK and Kricker A. How much melanoma is caused by sun exposure? Melanoma Res 1993; 3: 395-401.

8. Whiteman DC, Whiteman AC and Green AC. Childhood sun exposure as a risk factor for melanoma: a systematic review of epidemiological studies. Cancer Causes Control 2001; 12: 69-82.

9. Bataille V. Genetic epidemiology of melanoma. Eur J Cancer 2003; 39: $1341-1347$.

10. Hemminki K, Li X, Plna K, Granstrom C and Vaittinen P. The nation-wide Swedish family-cancer database-updated structure and familial rates. Acta Oncol 2001; 40 (6): 772-777.

11. Goldgar DE, Easton DF, Cannon-Albright LA and Skolnick MH. Systematic population-based assessment of cancer risk in first-degree relatives of cancer probands. J Natl Cancer Inst 1994; 86 (21): 1600-1608.

12. Hemminki $\mathrm{K}$, Zhang $\mathrm{H}$ and Czene K. Familial and attributable risks in cutaneous melanoma: effects of proband and age. J Invest Dermat 2002; 120: 217-223.

13. Swerdlow AJ, De Stavola B, Maconochie N and Siskind V. A population-based study of cancer risk in twins: relationships 
to birth order and sexes of the twin pair. Int J Cancer 1996; 67 (4): 472-478.

14. Hemminki K and Li X. Cancer risks in twins: results from the Swedish family-cancer database. Int J Cancer 2002; 99 (6): 873-878.

15. Milan T, Verkasalo PK, Kaprio J, Koskenvuo M and Pukkala E. Malignant skin cancers in the Finnish Twin Cohort: a population-based study, 1976-97. Br J Dermatol 2002; 147 (3): 509-512.

16. Czene K, Lichtenstein P and Hemminki K. Environmental and heritable causes of cancer among 9.6 million individuals in the Swedish Family-Cancer Database. Int J Cancer 2002; 99 (2): 260-266.

17. Greene MH and Fraumeni JF. The hereditary variant of familial melanoma, in: Clarh WH, Goldman LI and Mastrangelo MJ (Eds.), Human Malignant Melanoma, Grune and Stratton, New York, 1979; pp. 139-166.

18. Holman CD and Armstrong BK. Pigmentary traits, ethnic origin, benign nevi, and family history as risk factors for cutaneous malignant melanoma. J Natl Cancer Inst 1984; 72 (2): 257-266.

19. Cristofolini M, Franceschi S, Tasin L, Zumiani G, Piscioli F, Talamini R and La Vecchia C. Risk factors for cutaneous malignant melanoma in a northern Italian population. Int $\mathrm{J}$ Cancer 1987; 39 (2): 150-154.

20. Osterlind A, Tucker MA, Hou-Jensen K, Stone BJ, Engholm G and Jensen OM. The Danish case-control study of cutaneous malignant melanoma. I. Importance of host factors. Int J Cancer 1988; 42 (2): 200-206.

21. de Snoo FA, Bergman W and Gruis NA. Familial melanoma: a complex disorder leading to controversy on DNA testing. Fam Cancer 2003; 2: 109-116.

22. Tsao H. Update on familial cancer syndromes and the skin. J Am Acad Dermatol 2000; 42: 939-971.

23. Anderson DE, Smith JL, Jr. and McBride CM. Hereditary aspects of malignant melanoma. JAMA 1967; 200 (9): 741-746.

24. Lynch HT and Krush AJ. Heredity and malignant melanoma: implications for early cancer detection. Canad Med Assoc 1968; 99 (1): 17-21.

25. Whelan AJ, Bartsch D and Goodfellow PJ. Brief report: a familia syndrome of pancreatic cancer and melanoma with a mutation in the CDKN2 tumor-suppressor gene. New Eng J Med 1995; 33: 975-977.

26. Parker JF, Florell SR, Alexander A, DiSario JA, Shami PJ and Leachman SA. Pancreatic carcinoma surveillance in patients with familial melanoma. Arch Dermatol 2003; 139 (8): 1019-1025.

27. Borg A, Sandberg T, Nilsson K, Johannsson O, Klinker M Masback A, Westerdahl J, Olsson $\mathrm{H}$ and Ingvar C. High frequency of multiple melanomas and breast and pancreas carcinomas in CDKN2A mutation-positive melanoma families. J Natl Cancer Inst 2000; 92 (15): 1260-1266.

28. Weston B, Grufferman S, Kostvu D, Burton CS and Grant J. Familial aggregation of melanoma, basal cell carcinoma and gastric adenocarcinoma. Cancer 1986; 57: 2230-2234.

29. Kaufman DK, Kimmel DW, Parisi JE and Michels W. A familial syndrome with cutaneous malignant melanoma and cerebral astrocytoma. Neurology 1993; 43: 1728-1731.

30. Wassberg C, Thorn M, Yuen J, Hakulinen T and Ringborg U. Cancer risk in patients with earlier diagnosis of cutaneous melanoma in situ. Int J Cancer 1999; 83: 314-317.

31. Schmid-Wendter MH, Baumert J, Wendterb CM, Plewig G and Volkenandt $M$. Risk of second primary malignancies in patients with cutaneous melanoma. Br J Dermatol 2001; 145: 981-985.

32. Debniak T, Gorski B, Cybulski C, Jakubowska A, Kurzawski G, Kladny J, Zaluga E, Fiedorowicz J, Debniak B and Lubinski J.
Increased risk of breast cancer in relatives of malignant melanoma patients from families with strong cancer familial aggregation. Eur J Cancer Prev 2003; 12: 241-245.

33. Hussussian CJ, Struewing JP, Goldstein AM, Higgins PA, Ally DS, Sheahan MD, Clark WH Jr, Tucker MA and Dracopoli NC. Germline p16 mutations in familial melanoma. Nat Genet 1994; 8: 15-21.

34. Kamb A, Shattuck-Eidens D, Eeles R, Liu Q, Gruis NA, Ding W, Hussey C, Tran T, Miki Y, Weaver-Feldhaus J, et al. Analysis of the pl6 gene (CDKN2) as a candidate for the chromosome 9p melanoma susceptibility locus. Nat Genet 1994; 8: 23-26.

35. Serrano M, Hannon GJ and Beach D. A new regulatory motif in cell-cycle control causing specific inhibition of cyclin D/CDK4. Nature 1993; 366: 704-707.

36. Soufir N, Avril MF, Chompret A, Demenais F, Bombled J, Spatz A, Stoppa-Lyonnet D, Benard J and Bressac-de Paillerets B. Prevalence of p16 and CDK4 germline mutations in 48 melanoma-prone families in France. The French Familial Melanoma Study Group. Hum Mol Genet 1998; 7: 941.

37. FitzGerald MG, Harkin DP, Silva-Arrieta S, MacDonald DJ, Lucchina LC, Unsal H, O’Neill E, Koh J, Finkelstein DM, Isselbacher KJ, Sober AJ and Haber DA. Prevalence of germ-line mutations in p16, p19ARF, and CDK4 in familial melanoma: analysis of a clinic-based population. Proc Natl Acad Sci USA 1996; 93: 8541-8545.

38. Platz A, Hansson J and Ringborg U. Screening of germline mutations in the CDK4, CDKN2C and TP53 genes in familial melanoma: a clinic-based population study. Int J Cancer 1998; 25: 13-15.

39. Platz A, Hansson J, Mansson-Brahme E, Lagerlof B, Linder S, Lundqvist E, Sevigny P, Inganas M and Ringborg U. Screening of germline mutations in the CDKN2A and CDKN2B genes in Swedish families with hereditary cutaneous melanoma. J Natl Cancer Inst 1997; 89: 697-702.

40. Debniak T, Gorski B, Scott RJ, Cybulski C, Medrek K, Zowocka E, Kurzawski G, Debniak B, Kadny J, Bielecka-Grzela S, Maleszka R and Lubinski J. Germline mutation and large deletion analysis of the CDKN2A and ARF genes in families with multiple melanoma or an aggregation of malignant melanoma and breast cancer. Int J Cancer 2004; 1 10: 558-562.

41. Lamperska K, Karezewska A, Kwiatkowska E and Mackiewicz A. Analysis of mutations in the p16/CDKN2A gene in sporadic and familial melanoma in the Polish population. Acta Biochim Pol 2002; 49: 369-376.

42. Bressac-de-Paillerets B, Avril MF, Chompret A and Demenais F. Genetic and environmental factors in cutaneous malignant melanoma. Biochemie 2002; 84: 67-74.

43. Whiteman DC, Miligan A, Welch J, Green AC and Hayward NK. Germline CDKN2A mutations in childhood melanoma. J Natl Cancer Inst 1997; 89: 1460-1465.

44. Vasen HF, Gruis NA, Frants RR, van der Velden PA, Hille ET and Bergman W. Risk of developing pancreatic cancer in families with familial atypical multiple mole melanoma associated with a specific 19 deletion of p16 (p16-Leiden). Int J Cancer 2000; 87: 809-811.

45. Goldstein AM, Fraser MC, Struewing JP, Hussussian CJ, Ranade K, Zametkin DP, Fontaine LS, Organic SM, Dracopoli NC, Clark $\mathrm{WH} J \mathrm{r}$, et al. Increased risk of pancreatic cancer in melanoma-prone families with pl6INK4 mutations. New Engl J Med 1995; 333: 970-974.

46. Borg A, Sandberg T, Nilsson K, Johannsson $O$, Klinker M, Masback A, Westerdahl J, Olsson $\mathrm{H}$ and Ingvar C. High frequency of multiple melanomas and breast and pancreas carcinomas in CDKN2A mutation-positive melanoma families. J Natl Cancer Inst 2000; 92: 1260-1266. 
47. Bishop DT, Demenais F, Goldstein AM, Bergman W, Bishop JN, Bressac-de Paillerets B, Chompret A, Ghiorzo P, Gruis N, Hansson J, Harland M, Hayward N, Holland EA, Mann GJ, Mantelli M, Nancarrow D, Platz A, Tucker MA and Melanoma Genetics Consortium. Geographical variation in the penetrance of CDKN2A mutations for melanoma. J Natl Cancer Inst 2002; 94: 894-903.

48. Duro D, Bernard O, Della Valle V, Berger R and Larsen CJ. A new type of p16INK4/MTS1 gene transcript expressed in B-cell malignancies. Oncogene 1995; 11: 21-29.

49. Stone S, Jiang P, Dayananth P, Tavtigian SV, Katcher H, Parry D, Peters $G$ and Kamb A. Complex structure and regulation of the P16 (MTS1) locus. Cancer Res 1995; 55: 2988-2994.

50. Eymin B, Karayan L, Seite P, Brambilla C, Brambilla E, Larsen CJ and Gazzeri S. Human ARF binds E2F1 and inhibits its transcriptional activity. Oncogene 2001; 20: 1033-1041.

51. Randerson-Moor JA, Harland M, Williams S, Cuthbert-Heavens D, Sheridan E, Aveyard J, Sibley K, Whitaker L, Knowles M, Bishop JN and Bishop DT. A germline deletion of p1 4 (ARF) but not CDKN2A in a melanoma-neural system tumour syndrome family. Hum Mol Genet 2001; 10: 55-62.

52. Hewitt C, Lee Wu C, Evans G, Howell A, Elles RG, Jordan R, Sloan P, Read AP and Thakker N. Germline mutation of ARF in a melanoma kindred. Hum Mol Genet 2002; 11: 1273-1279.

53. Zuo L, Weger J, Yang Q, Goldstein AM, Tucker MA, Walker GJ, Hayward N and Dracopoli NC. Germline mutations in the pl 6INK4a binding domain of CDK4 in familial melanoma. Nat Genet 1996; 12: 97-9.

54. Goldstein AM, Chidambaram A, Halpern A, Holly EA, Guerry IV D, Sagebiel R, Elder DE and Tucker MA. Rarity of CDK4 germline mutations in familial melanoma. Melanoma Res 2002; 12: 51 -55.

55. The Breast Cancer Linkage Consortium. Cancer risks in BRCA2 mutation carriers. The Breast Cancer Linkage Consortium. J Natl Cancer Inst 1999; 91: 1310-1316.

56. Scott RJ, Vajdic CM, Armstrong BK, Ainsworth CJ, Meldrum CJ, Aitken JF and Kricker A. BRCA2 mutations in a population-based series of patients with ocular melanoma. Int J Cancer 2002 102: 188-191.

57. Johannsson $O$, Loman N, Moller T, Kristoffersson U, Borg A and Olsson $\mathrm{H}$. Incidence of malignant tumours in relatives of BRCA1 and BRCA2 germline mutation carriers. Eur J Cancer 1999; 35 1248-1257.

58. Varon R, Vissinga C, Platzer M, Cerosaletti KM, Chrzanowska KH, Saar K, Beckmann G, Seemanova E, Cooper PR, Nowak NJ, Stumm M, Weemaes CM, Gatti RA, Wilson RK, Digweed M, Rosenthal A, Sperling K, Concannon P and Reis A. Nibrin, a novel DNA double-strand break repair protein, is mutated in Nijmegen breakage syndrome. Cell 1998; 93: 467-476

59. Carney JP, Maser RS, Olivares H, Davis EM, Le Beau M, Yates JR 3rd, Hays L, Morgan WF and Petrini JH. The hMre 1 1/hRad50 protein complex and Nijmegen breakage syndrome: linkage of double-strand break repair to the cellular DNA damage response. Cell 1998; 93: 477-486.

60. Debniak T, Gorski B, Cybulski C, Jakubowska A, Kurzawski G, Lener M, Mierzejewski M, Masojc B, Medrek K, Kladny J, Zaluga E, Maleszka R, Chosia M and Lubinski J. Germline 657del5 mutation in the NBS1 gene in patients with malignant melanoma of the skin. Melanoma Res 2003; 13: 365-370.

61. Blasina A, de Weyer IV, Laus MC, Luyten WH, Parker AE and McGowan $\mathrm{CH}$. A human homologue of the checkpoint kinase $\mathrm{Cds} 1$ directly inhibits Cdc25 phosphatase. Curr Biol 1999; 14: 1-10.

62. Chaturvedi P, Eng WK, Zhu Y, Mattern MR, Mishra R, Hurle MR, Zhang X, Annan RS, Lu Q, Faucette LF, Scott GF, Li X, Carr SA, Johnson RK, Winkler JD and Zhou BB. Mammalian Chk2 is a downstream effector of the ATM-dependent DNA damage checkpoint pathway. Oncogene 1999; 18: 4047-4054.
63. Vahteristo $P$, Tamminen A, Karvinen P, Eerola $H$, Eklund $C$, Aaltonen LA, Blomqvist C, Aittomaki K and Nevanlinna H. p53, $\mathrm{CHK} 2$, and $\mathrm{CHK} 1$ genes in Finnish families with Li-Fraumeni syndrome: further evidence of $\mathrm{CHK} 2$ in inherited cancer predisposition. Cancer Res 2001; 61: 5718-5722.

64. Debniak T, Gorski B, Cybulski C, Kurzawski G, Zlowocka E, Kladny J, Chosia M and Lubinski J. Rarity of germline 1100 delC mutation in CHK2 in patients with malignant melanoma of the skin. Melanoma Res 2004; 14: 121-124.

65. Castiglia D, Pagani E, Alvino E, Vernole P, Marra G, Cannavo $E$, Jiricny J, Zambruno $G$ and D'Atri S. Biallelic somatic inactivation of the mismatch repair gene $\mathrm{MLH} 1$ in a primary skin melanoma. Genes Chromosomes Cancer 2003; 37: 165-175.

66. Baccarelli A, Calista D, Minghetti P, Marinelli B, Albetti B, Tseng T, Hedayati M, Grossman L, Landi G, Struewing JP and Landi MT. XPD gene polymorphism and host characteristics in the association with cutaneous malignant melanoma risk. $\mathrm{Br} \mathrm{J}$ Cancer 2004; 90: 497-502.

67. Tomescu D, Kavanagh G, Ha T, Campbell H and Melton DW. Nucleotide excision repair gene XPD polymorphisms and genetic predisposition to melanoma. Carcinogenesis 2001; 22: 403-408.

68. Valverde P, Healy E, Jackson I, Rees JL and Thody AJ. Variants of the melanocyte-stimulating hormone receptor gene are associated with red hair and fair skin in humans. Nat Genet 1995; $11: 328-330$

69. Palmer JS, Duffy DL, Box NF, Aitken JF, O'Gorman LE, Green AC, Hayward NK, Martin NG and Sturm RA. Melanocortin-1 receptor polymorphisms and risk of melanoma: is the association explained solely by pigmentation phenotype? Am J Hum Genet 2000; 66: 176-186.

70. Box NF, Wyeth JR, O'Gorman LE, Martin NG and Sturm RA. Characterization of melanocyte stimulating hormone receptor variant alleles in twins with red hair. Hum Mol Genet 1997; 6: $1891-1897$.

71. Box NF, Duffy DL, Chen W, Stark M, Martin NG, Sturm RA and Hayward NK. MC1R genotype modifies risk of melanoma in families segregating CDKN2A mutations. Am J Hum Genet 2001; 69: 765-773.

72. van der Velden PA, Sandkuijl LA, Bergman W, Pavel S, van Mourik L, Frants RR and Gruis NA. Melanocortin-1 receptor variant R151C modifies melanoma risk in Dutch families with melanoma. Am J Hum Genet 2001; 69: 774-779.

73. Bataille V, Bishop JA, Sasieni P, Swerdlow AJ, Pinney E, Griffiths $\mathrm{K}$ and Cuzick J. Risk of cutaneous melanoma in relation to the numbers, types and sites of naevi: a case-control study. $\mathrm{Br} \mathrm{J}$ Cancer 1996; 73 (12): 1605-1611.

74. Briollais L, Chompret A, Guilloud-Bataille M, Feingold N, Avril MF and Demenais F. Genetic and epidemiological risk factors for a malignant melanoma-predisposing phenotype: the great number of nevi. Genet Epidemiol 1996; 13 (4): 385-402.

75. Wachsmuth RC, Harland M and Bishop JA. The atypical-mole syndrome and predisposition to melanoma. N Engl J Med 1998; 339 (5): 348-349.

76. Bataille V, Snieder H, MacGregor AJ, Sasieni P and Spector TD. Genetics of risk factors for melanoma: an adult twin study of nevi and freckles. J Natl Cancer Inst 2000; 92 (6): 457-463.

77. Goldgar DE, Cannon-Albright LA, Meyer LJ, Piepkorn MW, Zone $\mathrm{JJ}$ and Skolnick $\mathrm{MH}$. Inheritance of nevus number and size in melanoma and dysplastic nevus syndrome kindreds. J Natl Cancer Inst 1991; 83 (23): 1726-1733.

78. Grange F, Chompret A, Guilloud-Bataille M, Guillaume JC, Margulis A, Prade M, Demenais F and Avril MF. Comparison between familial and nonfamilial melanoma in France. Arch Dermatol 1995; 131 (10): 1154-1159. 